\title{
HISTOPATHOLOGICAL AND HISTOCHEMICAL STUDY OF THE EFFECTS OF VITAMIN C ON BISPHENOL A TOXICITY IN ALBINO RATS
}

By

\section{Mohamed Nafea Al-Sayed, Magdy Mohamed Sherif, Nagy Mohamed Al- Fadaly, Ashraf Ibrahim Hasan and Sayed Abd El-Rehiem Sayed*}

\author{
Departments of Forensic Medicine \& Clinical Toxicology and Pathology*, Faculty of \\ Medicine, Al-Azhar University
}

Corresponding author: Mohamed Nafea Al-Sayed, E-mail: mnafea93@gmail.com

\begin{abstract}
Background: The harmful effect of a phenolic type of environmental toxicant, known as bisphenol A (BPA), has achieved great relevance. The interest in this compound is increasing owing to its possible adverse effects on several organs, which has led several organizations to recommend the prohibition or at least reduction.

Objective: To study histopathological and histochemical changes caused by Bisphenol A in the kidney and testis of albino rats, and to identify the potential protective role of vitamin C on Bisphenol A toxicity.

Materials and Methods: One hundred (100) adult healthy male albino rats Western strain weighing 180 $220 \mathrm{~g}$ were obtained from the animal house, Faculty of Medicine, Assiut University, Egypt, and housed in a clean capacious macro-lane cages ( 5 per cage which was $60 \times 40 \times 25 \mathrm{~cm}$ ) under standard laboratory conditions including good aerated room with suitable temperature, relative humidity, maintained at good light with normal light/dark cycles. All rats were given normal rat diet during the experimental period with free access to water.

Results: Bisphenol A has deleterious effects on the histological structure of the testis and kidney of albino rats. Testis and kidney of rat administrated vitamin $\mathrm{C}$ in combination with Bisphenol A showed marked amelioration of the degenerative changes that were observed in rats administrated Bisphenol A alone. Effects of Bisphenol A on testis and kidney of rat after recovery for two weeks were still as in group II, while other effects become worse. The only effects which disappeared were hemorrhage and inflammatory infiltration.
\end{abstract}

Conclusion: BPA has many toxic adverse health effects including reproductive and renal toxicity.

Keywords: Bisphenol A, Vitamin C, Albino Rats.

\section{INTRODUCTION}

Environmental pollution has become a major concern in the developed as well as under-developed

countries. Approximately 70000 anthropogenic chemicals are released into the aquatic ecosystems (Ozden, 2010). Among these, there is wide ranges that shows affinity towards estrogen receptor and are structurally similar to natural or pharmaceutical estrogens; such chemicals are now called endocrine disrupting chemicals (EDCs) (Sumpter, 2010).

Endocrine-disrupting chemicals have been the focus of scientific research. Among those, bisphenol A (BPA) is used as the monomer to manufacture epoxy, polycarbonate, and corrosion-resistant unsaturated polyester-styrene resins required for food-packaging materials in 
industrial processing (Milman et al., 2010).

The global BPA capacity alone was reported to be 2,214,000 metric tons, with 6-10\% growth in demand expected per year about 100 tons is released into the atmosphere each year (Alonso-Magdalena et al., 2010).

Endocrine disruptors cause adverse health effects in humans and wildlife subsequent to changes in endocrine function. BPA is among the chemicals identified as a potential endocrine disruptor based on its estrogenic properties. Studies in laboratory animals have focused on understanding the consequences of BPA for estrogenic activity, taking into account the variety of estrogen receptors (ER) and estrogen binding molecules and their functions in different reproductive processes and different stages of the life cycle. Estrogen has a pervasive effect on body function in both males and females through a variety of mechanisms. The action of BPA at $\mathrm{ER} \alpha, \mathrm{ER} \beta$, estrogen related receptor (ERR), and the estrogen membrane receptor (mER) has been documented (Wetherill et al., 2011).

Spermatogenesis is dependent on a well-orchestrated hormonal environment. Leydig cells stimulated by LH provide the local production of testosterone, and Sertoli cells stimulated by FSH provide the local production of estradiol. In addition, Sertoli cells maintain the spermatogonial stem cells responsible for the continuity of spermatogenesis. BPA exposure caused an imbalance in these hormones, which may have contributed to defects in spermatogenesis and sperm maturation (Wisniewski et al., 2015).
The present work was designed to study histopathological and histochemical changes caused by Bisphenol $\mathrm{A}$ in the kidney and testis of albino rats and to identify the potential protective role of vitamin C on Bisphenol A toxicity.

\section{MATERIALS AND METHODS}

One hundred (100) adult healthy male albino rats western strain weighting 180 $220 \mathrm{~g}$ were obtained from the animal house, Faculty of Medicine, Assiut University, Egypt and housed in a clean capacious macro-lane cages ( 5 per cage which was $60 \times 40 \times 25 \mathrm{~cm}$ ) under standard laboratory conditions including good aerated room with suitable temperature, relative humidity, maintained at good light with normal light/dark cycles. All rats were given normal rat diet during the experimental period with free access to water.

\section{Chemicals:}

1. Bisphenol A compound $99.9 \%$ (Sigma Company).

2. Corn oil as a vehicle purchased from ARMA Co. Egypt.

3. Vitamin C (ascorbic acid) powder (Sigma Company).

4. Ethyl alcohol 100\% (El Naser pharmaceutical Chemical Co., Egypt).

5. Ether anesthesia (El Naser pharmaceutical Chemical Co., Egypt).

6. Paraffin wax (El Naser pharmaceutical Chemical Co., Egypt).

7. Hematoxyline and Eosine stain (Sedico Co. Egypt). 
The animals were classified into four groups:

1. Control group (vehicle control group I): Each animal was given $1 \mathrm{ml}$ of the vehicle which was corn oil orally by gavage for three months.

2. Treated group 1 (group II): Each animal was given bisphenol A compound dissolved in corn oil at a dose of $320 \mathrm{mg} / \mathrm{kg} /$ day orally by gavage (which represented 1/10 LD50) for 3 months.

3. Treated group 2 (group III): Each animal was given bisphenol A compound dissolved in corn oil at a dose of $320 \mathrm{mg} / \mathrm{kg} /$ day orally by gavage (which represented 1/10 LD50) and vitamin-C (200mg/kg/day) orally by gavage for 3 months.

4. Recovery group (group IV): Each animal was given bisphenol A compound dissolved in corn oil at a dose of $320 \mathrm{mg} / \mathrm{kg} /$ day orally by gavage (which represented 1/10 LD50) for 3 month only, but postponed slaughter for two weeks.

The rats were weighed at the beginning of the study, and then 2 times weekly until the end of work to calculate the dose of the drug according to the weight. At the end of this period and under ether anesthesia all animals were sacrificed after 24 hours of the last dose. The testis and kidneys were weighed and processed for examination of possible histopathological and histochemical changes.

\section{Histopathological Examination:}

Processing of Paraffin sections (Drury and Wallington, 1980):
1. The specimens were fixed in $10 \%$ buffered neutral formalin for at least 7 days.

2. Fixation was followed by dehydration in ascending grades of ethyl alcohol (50\%, 70\%, $96 \%$ and absolute alcohol).

3. The specimens were cleared in xylol.

4. The specimens were impregnated with soft paraffin by putting them in several changes of melted wax (melting point $50 \mathrm{oC}$ ) in an oven.

5. Embedding in hard paraffin was done by putting specimens in melted wax (melting point $55 \mathrm{oC}$ ), poured into a mold and then cooled to form paraffin blocks containing the specimens.

Serial sections 5-8 micrometers were sliced, mounted on slides and stained with Hematoxylin and Eosin stain.

\section{Histochemical Examination:}

Masson's trichrome stain (Fawcett and Jensh, 2002): It was valuable for distinguishing elements of connective tissue. Typically the cell cytoplasm, muscle and keratin were stained red, nuclei were black and collagen was blue. This stain benefit were from having tissue fixed using Bouin's fixative or formalinfixation.

Periodic acid Schiff (PAS) (Bancroft and Gamble, 2002): This strained carbohydrates magenta, including components of the basal lamina, surface glycoproteins on cells and intracellular carbohydrates such as glycogen in hepatocytes. Cells that secreted mucus were also strongly stained (Glycogen and other carbohydrates appeared magenta, nuclei appeared blue). 


\section{RESULTS}

Table (1) showed histopathological effects on the kidney as follow:

Distorted glomeruli in group II (bisphenol A $320 \mathrm{mg} / \mathrm{kg} /$ day), group III (bisphenol A + vitamin-C (200mg/kg/day) and group IV (recovery from bisphenol A. Narrow Bowman's space in group II, group III and group IV. Mildly edematous proximal tubular lining group II, group III and group IV. Intra-tubular casts in group
II which was average in group III due to presence of vitamin-C, group IV showed edematous /apoptotic lining of collecting tubules. Marked inflammatory infiltrate in group II which disappeared with vitamin$\mathrm{C}$ in group III and after recovery in group IV. Moderate hemorrhage in group II which absent with vitamin-C in group III and disappear after recovery in group IV.

Table (1): Histopathological changes in kidney and effects on kidney

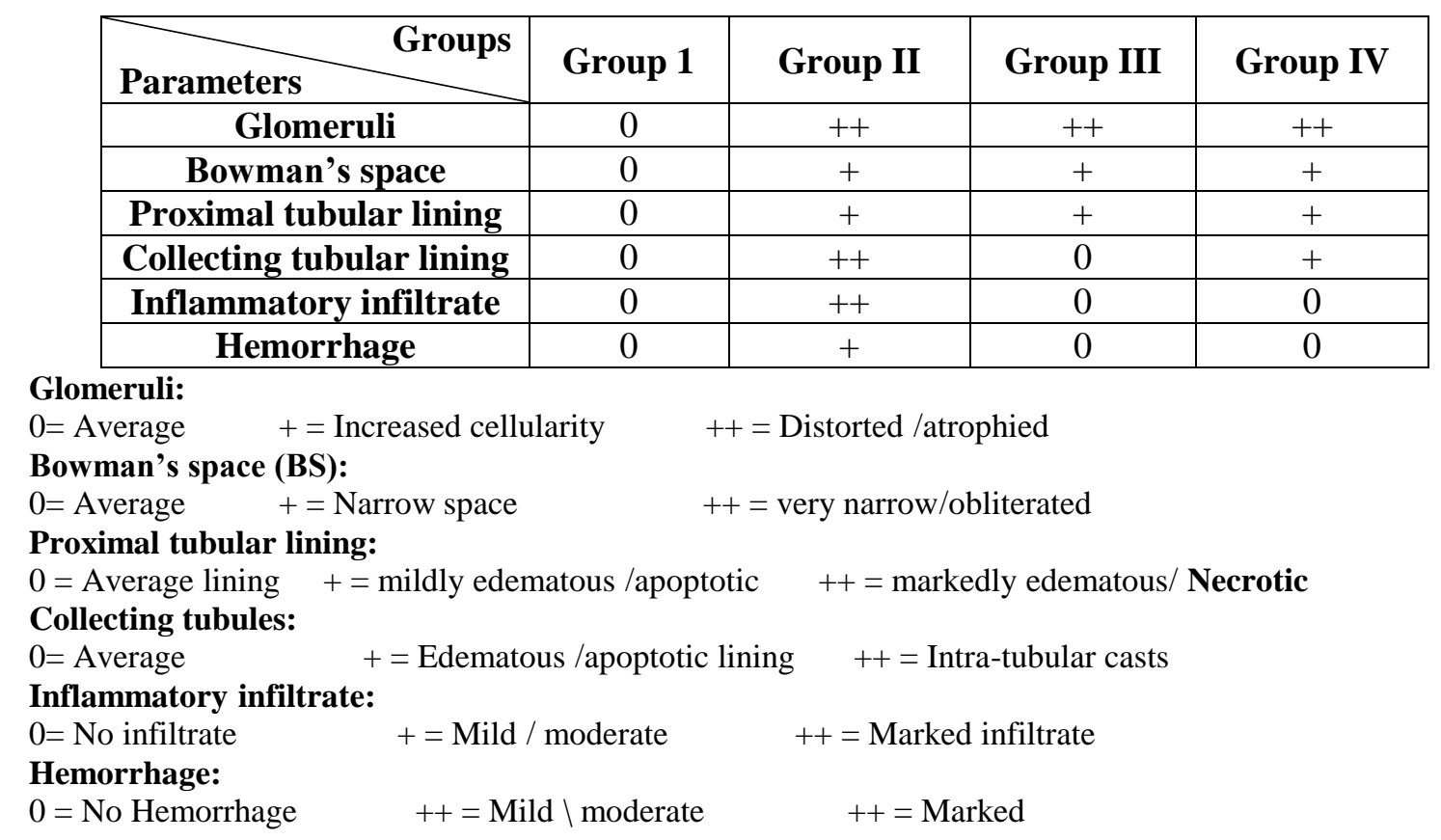




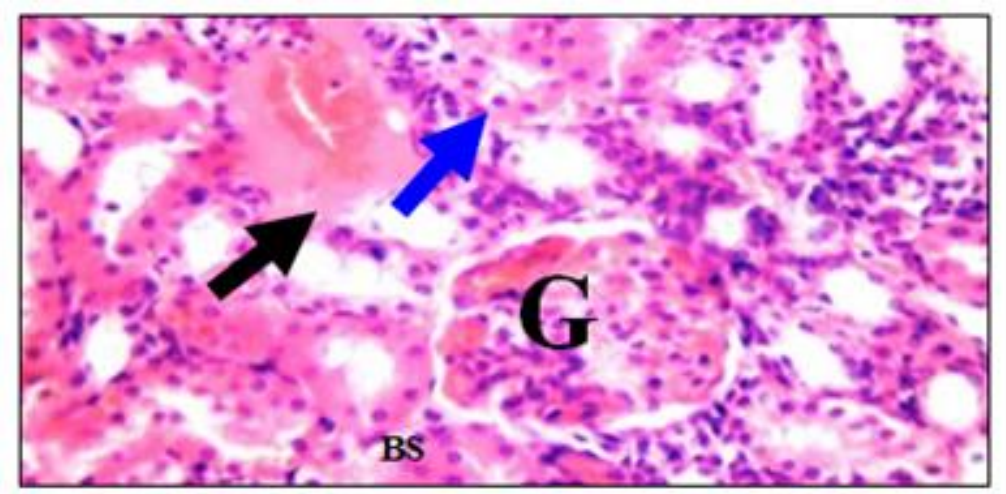

Figure (1): (Bisphenol A): Distorted glomerulus (G) with narrow Bowman's space (BS), proximal tubules $(\mathrm{P})$ showing mildly edematous epithelial lining (blue arrow), and small area of hemorrhage (black arrow) (H\&E / X 400)

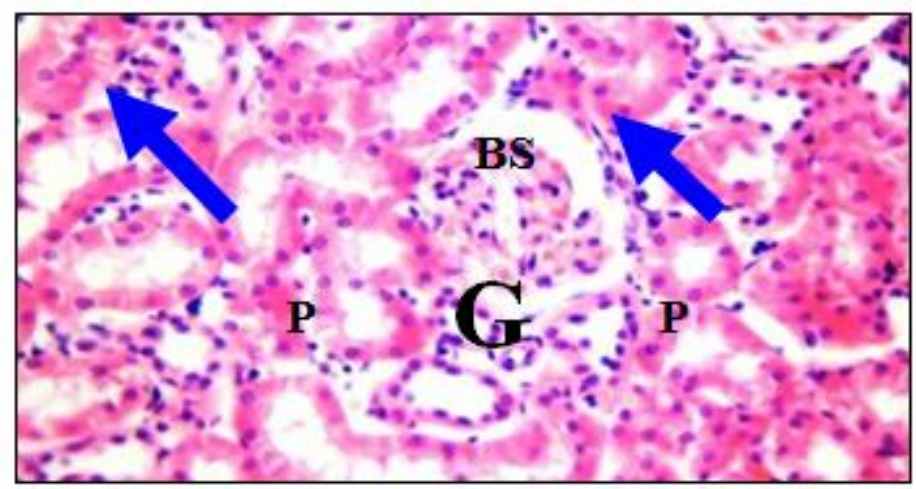

Figure (2): (Recovery from bisphenol A): Hypocellular distorted glomerulus (G) with wider Bowman's space (BS) and proximal tubules (P) showing apoptotic epithelial lining (blue arrows) (H\&E / X 400)

Table (2): showed PAS scoring of all groups as follow:

Mild to moderate thickening of glomerular BM in group II, group III and group IV. loss of brush border of proximal tubules in more than $10 \%$ of tubules in group II but in group III loss in less than $10 \%$ of tubules due to presence of
vitamin-C, after recovery still loss brush border of proximal tubules in more than $10 \%$ of tubules in group IV. No effects on Tubular BM all groups .control group (group 1) show average glomerular BM and tubular BM and preserve brush border of proximal tubules. (Figure 3)

Table (2): Scoring of all groups in kidney

\begin{tabular}{|c|c|c|c|c|}
\hline Parameters & Glomerular & \multicolumn{2}{|c|}{ Proximal tubules } & Collecting tubular \\
\cline { 3 - 4 } Groups & BM & Brush border & BM & 0 \\
\hline Group 1 & 0 & 0 & 0 & 0 \\
\hline Group II & + & ++ & 0 & 0 \\
\hline Group III & + & + & 0 & 0 \\
\hline Group IV & + & ++ & 0 & 0 \\
\hline
\end{tabular}

Glomerular BM: $0=$ Average $\quad+=$ Mild/moderate thickening $\quad++=$ Marked thickening

Brush border: $0=$ Preserved $+=$ Lost in $<10 \% \quad++=$ Lost in $>10 \%$ of tubules

Tubular BM: $0=$ Average $\quad+=$ Mild/moderate thickening $\quad++=$ Marked thickening 


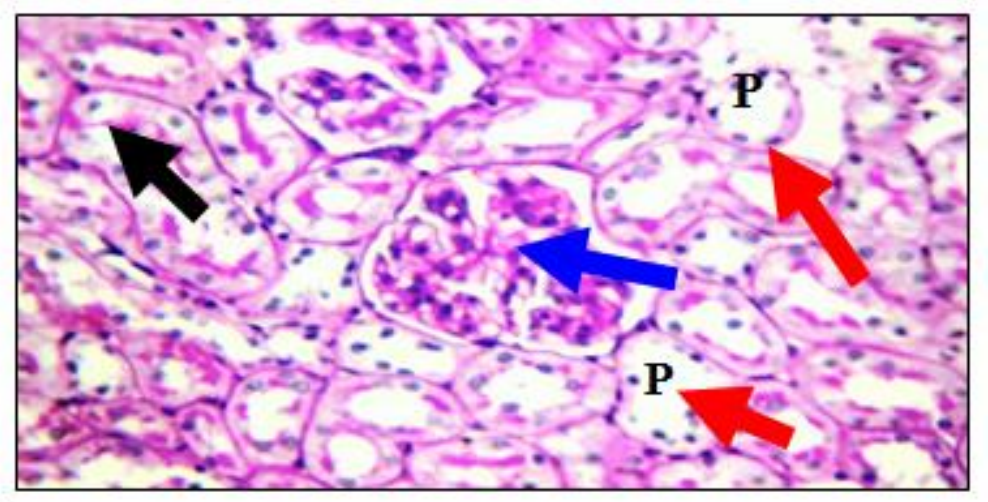

Figure (3): (Bisphenol A): Mildly thick glomerular basement membrane (blue arrow), some proximal tubules showing preserved BM and brush borders (black arrow) and others showing loss of brush borders (red arrows) (PAS stain / X 400)

Table (3): showed Masson trichrome stain results of all groups as follow:

Thin irregular collagen fibers in the cortex of Group II which become thick irregular collagen fibers in Group IV after recovery but thin regular collagen fibers (no changes) in Group III due to presence of vitamin-C. No changes on medulla in all groups. (Figure 4)

Table (3): Masson trichrome stain results of all groups

\begin{tabular}{|c|c|c|c|c|}
\hline $\begin{array}{l}\text { Collagen fibers } \\
\text { Stained deep blue }\end{array}$ & Group 1 & Group 1I & Group III & Group 1V \\
\hline Cortex & - & + & - & ++ \\
\hline Medulla & - & - & - & - \\
\hline
\end{tabular}

- = Negative: thin regular collagen fibers

- $\quad+=$ Thin irregular collagen fibers

- $\quad++=$ Thick irregular collagen fibers

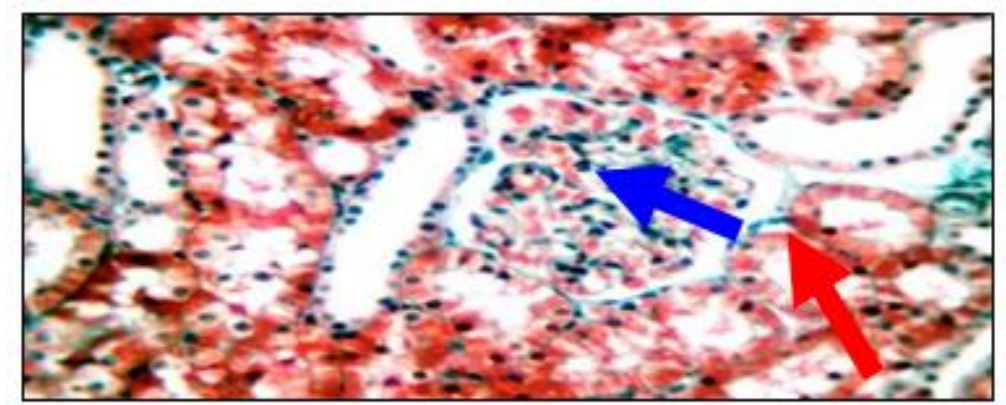

Figure (4): (Bisphenol A): Glomerular (blue arrows) and peri-tubular (red arrow) thin irregular collagen fibers (Masson trichrome stain X 40) 


\section{Effects on Testis}

Table (4): showed histopathological effects on the testis as follow:

Mildly thick capsule in group II, while preserved (average) in group III and group IV. Sclerotic tubules in more than $10 \%$ in group II and group IV while sclerotic tubules in less than $10 \%$ in group III .
Reduced germinal lining in group II and group III, while markedly reduced in group IV. Disorganized spermatogenesis in group II and group IV, while complete in group III, and mildly separated tubules in group II, III and IV. (Figure 6)

Table (4): Histopathological changes in testis.

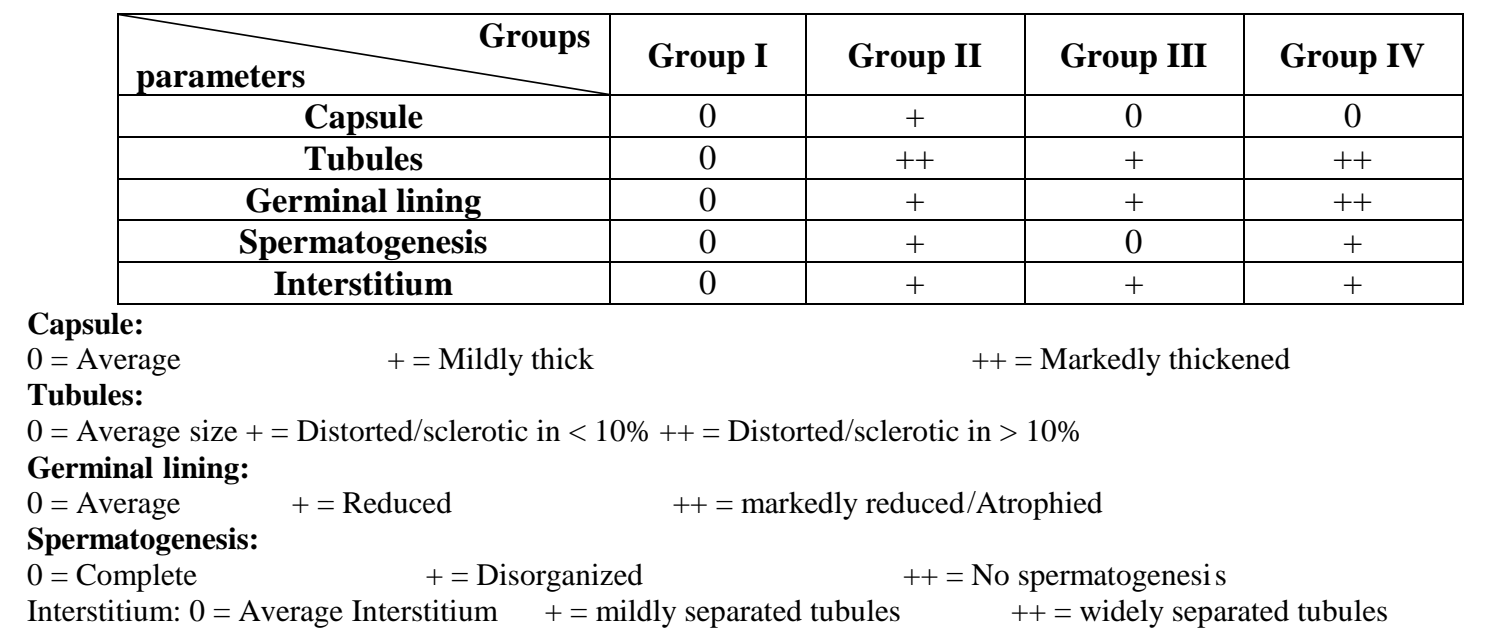

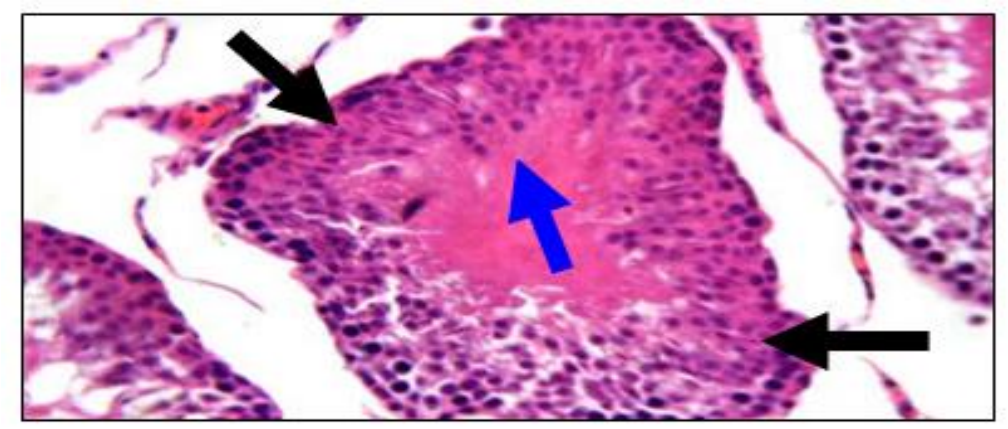

Figure (5): (Bisphenol A): Distorted partially sclerotic tubule with marked reduction of spermatogenesis (blue arrow) and irregular basement membrane (black arrows) (H\&E X / 400)

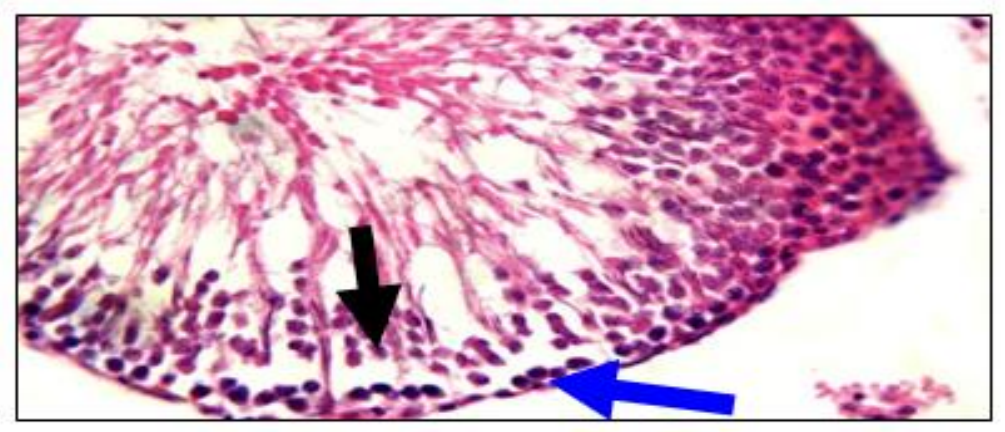

Figure (6): (Bisphenol A +Vit C): Average tubule with detached lining (blue arrow) and full spermatogenesis (black arrow) (H\&E X 400) 


\section{PAS scoring of all groups: (Figure 7)}

Basement membrane was mild thickened in groups II and IV while average in group III and control group.

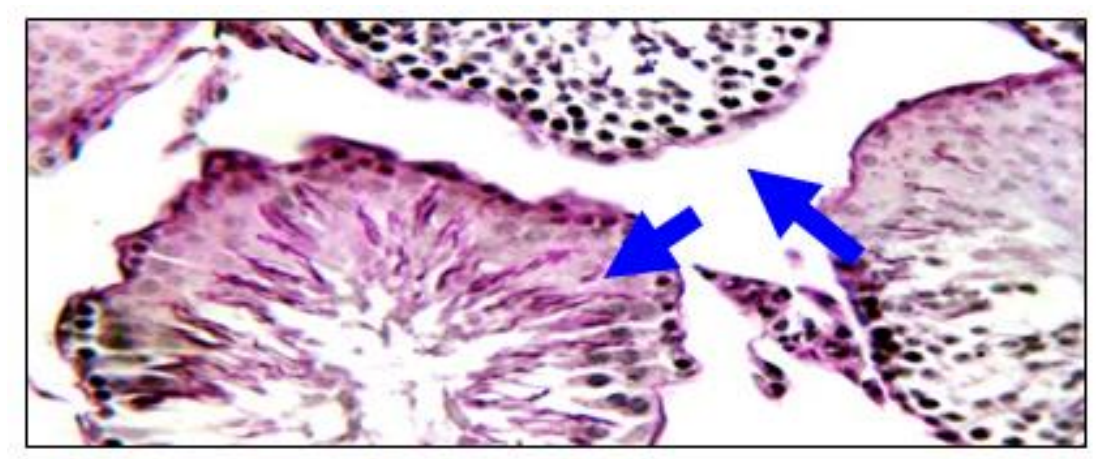

Figure (7): (Bisphenol A): Testicular tissue showing mild thickening of basement membrane (blue arrows) (PAS stain / X 400).

\section{Masson trichrome stain results of all groups:}

Basement membrane thickened in groups II and IV, while average in group III and control group.

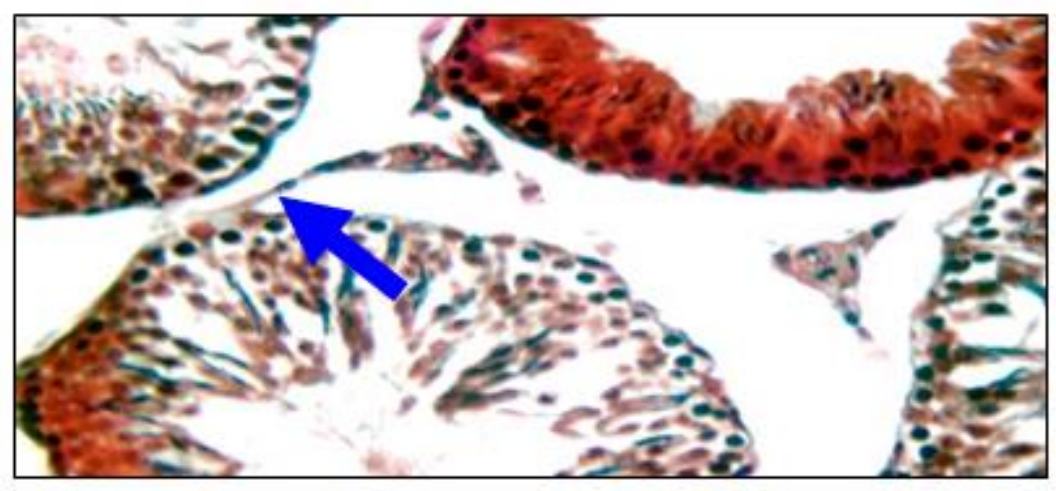

Figure (8): (Bisphenol A): Testicular tissue showing mild thickening of basement membrane (blue arrow) (Masson trichrome stain / X 400)

\section{DISCUSSION}

Kortenkamp (2014) demonstrated that BPA exposure in adults exposed to 0.02 $\mathrm{mg} / \mathrm{kg}$ for 6 days compromises the daily sperm production, preventing its normal increase from 14 to 18 weeks (Ashby et al., 2003).

Kourouma et al. (2014) observed a reduction in epididymal sperm motility and count in a dose dependent manner for the 10 and $50 \mathrm{mg} / \mathrm{kg}$ treatment groups.

In humans, a prospective study in couples undergoing medically assisted reproduction identified BPA residues in $98 \%$ of the patient urine samples, and the amount of BPA was inversely correlated with sperm concentration and motility (Knez et al., 2014). 
BPA exposure is likely not solely responsible for modifications to human sperm parameters. The reduction in sperm production could be associated with the disruption of the spermatic cycle. In adulthood, BPA exposure decreases sperm count via the reduction in type $A$ spermatogonial, spermatocytes and spermatids (Jin et al., 2013).

The processes of spermatogenesis begin with differentiation of spermatogonia which requires testosterone action. A study performed by Rosnah et al. (2014) showed significant lower level of free plasma testosterone and 17 $\beta$ oestradiol in the BPA-treated animals. It is postulated that the low testosterone level may have caused failure of spermatogenesis and disruption of the seminiferous epithelium. The low plasma testosterone level in BPA treated animals was probably due to interference of proliferative activity and development of Leydig cells in rat.

In the present study, BPA treated groups showed variable degrees of histopathological abnormalities in the testes which improved when adding vitamin $\mathrm{c}$ and does not change after recovery. Mildly thick capsule in group II (bisphenol A $320 \mathrm{mg} / \mathrm{kg} /$ day) while preserved (average) in group III (bisphenol A + vitamin-C (200mg/kg/day) and group IV (recovery from bisphenol A(. Sclerotic tubules in more than $10 \%$ in group II and group IV while sclerotic tubules in less than $10 \%$ in group III. Reduced germinal lining in group II and group III while markedly reduced in group IV. Disorganized Spermatogenesis in group II and group IV while complete in group III. Mildly separated tubules in group II, III and IV with H\&E stain. Basement membrane was mild thickened in groups II and VI while average in group III and control group (group I) with PAS stain. With Masson trichrome stain Basement membrane was thickened in groups II and VI, while average in group III and control group (group I).

Wisniewski et al. (2015) in their study stated that BPA exposure during adulthood: (a) reduced the total and daily sperm production by $50 \%$ at dosages of 5 $\mathrm{mg} / \mathrm{kg}$ and $25 \mathrm{mg} / \mathrm{kg}$; (b) reduced the sperm reserves in all segments of the epididymis for all BPA-treated groups by at least $70 \%$ and (c) reduced the sperm transit time in the caput, corpus and cauda epididymis by $50 \%$.

In the present study, BPA treated groups showed variable degrees of histopathological abnormalities in the kidney which improved when adding vitamin $\mathrm{c}$ and does not change after recovery. With H\&E stain distorted glomeruli in group II, group III and group IV. Narrow Bowman's space in group II, group III and group IV. Mildly edematous Proximal tubular lining group II, group III and group IV. Intra-tubular casts in group II which was average in group III due to presence of vitamin-C, group IV show edematous /apoptotic lining of collecting tubules. Marked inflammatory infiltrate in group II which disappear with vitamin-C in group III and after recovery in group IV. Moderate hemorrhage in group II which absent with vitamin-C in group III and disappear after recovery in group IV .with PAS stain mild to moderate thickening of glomerular BM in group II , group III (bisphenol $\mathrm{A}+$ vitamin-C and group IV. loss of brush border of Proximal 
tubules in more than $10 \%$ of tubules in group II but in group III loss in less than $10 \%$ of tubules due to presence of vitamin-C, after recovery still loss brush border of proximal tubules in more than $10 \%$ of tubules in group IV. No effects on Tubular BM all groups, with Masson trichrome stain thin irregular collagen fibers in the cortex of group II which become thick irregular collagen fibers in group $1 \mathrm{~V}$ after recovery but thin regular collagen fibers (no changes) in group III due to presence of vitamin-C . No changes on medulla in all groups.

Sangai et al. (2012) stated that oral administration of BPA for 30 days caused distortion of the tubules, increased vacuolization, necrosis, disorganization of glomerulus and increased space between the glomerulus and the capsule wall. The effects were more pronounced in highdose groups than that of low-dose groups of BPA.

In a study performed by Sewelam and Mokhtar (2019), multiple degenerative changes in the renal cortex were apparently progressive through the successive postnatal weeks and became less severe at 9th PW. Glomerular necrosis, adhesion, lobulation and hypercellularity with either wide or obliterated urinary spaces were well demonstrated. In addition, proximal tubular cellular swelling with obliterated lumen, cytoplasmic vacuolization, necrosis, pyknosis, tubular dilation and intertubular congestion were observed following BPA administration.

Hassan and Khudir (2013) claimed that, in BPA treated rats, accumulated BPA metabolites and in ability of renal excretion might affect renal tissue with subsequent tubular epithelial necrosis, degeneration and marked congestion.

Abd Elghaffar et al. (2015) concluded that exposure of rats to ACR caused testicular oxidative stress associated with histopathological changes in seminiferous tubules and reduction in testosterone in serum. Co-treatment of rats with garlic oil ameliorate the toxicity of ACR in rat testes by alleviating LPO and NO through scavenging of free radicals and enhancing the activity of SOD and CAT and GSH level.

In a study performed by Sangai et al. (2012), cotreatment of quercetin (which is a potent antioxidant found in various fruits and vegetables) and BPA caused significant mitigation in morphological alterations, body weight as well as absolute and relative weights of liver and kidney compared with only BPA-treated groups.

The administration of vitamin $\mathrm{C}$ to nephrotoxic rat's dose dependently increases plasma vitamin C concentrations, and thus, the resistance of plasma to lipid peroxidation. Plasma and body saturation with vitamin $\mathrm{C}$ at high dose in rats appears desirable to maximize tissue antioxidant protection and lowers the risk of oxidative damages in gentamicin nephrotoxicity (Derakhshanfar et al., 2013).

Exposures of Bisphenol-A and supplement of vitamin-C showed recovery in hepatic cells, interrenal cells and uriniferous tubules as compared to Bisphenol-A group. These showed that vitamin-C denotes as antidote against Bisphenol toxicity in Cirrhinus mrigala (Murmu and Shrivastava, 2011). 


\section{CONCLUSION}

BPA has many toxic adverse health effects including reproductive and renal toxicity. Histopathological and histochemical study with H\&E, PAS and Masson stains of testicular and renal tissues of albino rats administrate BPA and vitamin $\mathrm{C}$ suggesting the important role of vitamin $\mathrm{C}$ on minimizing hazards of Bisphenol A.

\section{REFERENCES}

1. Abd Elghaffar SKH, Ahmed EA and Omar HEM (2015): Acrylamide Induced Testicular Toxicity in Rats: Protective Effect of Garlic Oil. iMed Pub Journals, Biomarkers Journal, 1(5): 1-8.

2. Alonso-Magdalena $\mathbf{P}$, Ropero $\mathbf{A B}$, Soriano S, Quesada I and Nadal A. (2010): Bisphenol-A: a new diabetogenic factor? Hormones (Athens), 9: 118-126.

3. Bancroft JB and Gamble M. (2002): Theory and Practice of Histological Techniques. 5th ed., Pbl. Churchill Livingstone, Pp. 377-694.

4. Derakhshanfar A, Roshanzamir M and Bidadkosh A (2013): Dose-related protecting effects of vitamin $\mathrm{C}$ in gentamicin-induced rat nephrotoxicity: a histopathologic and biochemical study. Comp Clin Pathol., 22:441-447.

5. Drury RAB and Wallington EA. (1980): Carleton's Histological Technique". 5th ed., Oxford University Press, Pbl. London, New York and Toronto, Pp. 85-237.

6. Fawcett DW and Jensh RP. (2002): Bloom and Fawcett's Concise Histology. 2nd ed., Hodder Headline Group, Pbl. London, Pp. 237-246.

7. Hassan AH, Ismail AA and Khudir AN (2013): Effects of Pre-and Postnatal Exposure to Bisphenol- A on the
Reproductive Efficacy in Male Albino Rats. Journal of Kerbala University Scientific, 11 (3):158 172.

8. Jin P, Wang $X$, Chang F, Bai Y, Li Y, Zhou $R$ and Chen $L$ (2013): Low dose bisphenol A impairs spermatogenesis by suppressing reproductive hormone production and promoting germ cell apoptosis in adult rats. J Biomed Res., 27: 135-144.

9. Knez J, Kranvogl R, Breznik BP, Voncina E and Vlaisavljevic V. (2014): Are urinary bisphenol A levels in men related to semen quality and embryo development after medically assisted reproduction? Fertil Steril., 101: 215-221.

10. Kortenkamp A. (2014): Ten years of mixing cocktails: a review of combination effects of endocrine-disrupting chemicals. Environ Health Perspect., 115: 98-105.

11. Kourouma A, Peng D, Chao Q, Changjiang, Chengmin W, Wenjuan $F$, Suqin $Q$, Tingting $Y$ and Kedi $Y$ (2014): Bisphenol A induced reactive oxygen species (ROS) in the liver and affect epididymal semen quality in adults Sprague-Dawley rats. J Toxicol Environ Health Sci., 6(4):103-112.

12. Milman HA, Bosland MC, Walden PD and Heinze JE. (2010): Evaluation of the adequacy of published studies of low-dose effects of bisphenol $\mathrm{A}$ on the rodent prostate for use in human risk assessment. Regul Toxicol Pharmacol., 35: 338-346.

13. Murmu S and Shrivastava VK. (2011): Protective Action of an Anti-oxidant (Vitamin-C) Against Bisphenol-toxicity in Cirrhinus mrigala (Ham.). Turk J Fish Aquat Sci., 11: 25-29.

14. Ozden O (2010): Micro, macro mineral and proximate composition of Atlantic bonito and horse mackerel: a monthly differentiation. Int $\mathbf{J}$ Food Sci Tech., 45:578-586. 
15. Rosnah G, Normadiah MK, Das $S$ and Mustafa AM (2014): Detrimental effects of BISPHENOL A on development and functions of the male reproductive system in experimental rats. EXCLI Journal, 13:151-160.

16. Sangai NP, Verma RJ and Trivedi MH (2012): Testing the efficacy of quercetin in mitigating bisphenol A toxicity in liver and kidney of mice. Toxicol Ind Health, 30(7):581-97.

17. Sewelam AS and Mokhtar HE (2019): Effect of Perinatal Exposure to Low Dose Bisphenol A on Hepatic and Renal Tissues of Male Albino Rat Offspring: Histological, Immunohistochemical and Morphometric Studies. Egy. J. of Histology, 42:974-1000.

18. Sumpter PJ. (2010): Endocrine disruption in the Aquatic Environment. In: The Handbook of Environmental Chemistry, Endocrine Disruptors. Pbl.
Springer-Verlag, Berlin Heidelberg, Vol 3, Part M, Pp. 1806-18.

19. Wetherill YB, Akingbemi BT, Kanno J, McLachlan JA, Nadal A, Sonnenschein C, Watson CS, Zoeller RT and Belcher SM. (2011): In vitro molecular mechanisms of bisphenol A action. Reproductive Toxicology, 24: 178-98.

20. Wisniewski P, Romano RM, Kizys MM, Oliveira KC, Kasamatsu $T$, Giannocco G, Chiamolera MI, Dias-daSilva MR and Romano MA. (2015): Adult exposure to bisphenol A (BPA) in Wistar rats reduces sperm Quality with disruption of the hypothalamic-pituitarytesticular axis. Toxicology, 329: 1-9. 
در اسة التأثير ات النسيجية المرضية و الكيميائية لتأثنير فيتامين سىى على سمية البسفينول أ في جرذان التجارب البي البيضاء محمد نافع السيد، مجدى محمد شريف، ناجى محمد الفضالى، أشرف إبراهيم حسن،

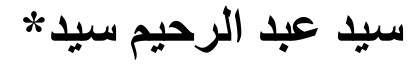

قسمي الطب الشرعى والسموم الإكلينيكية، الباتولوجيا العامةث، كلية الطب، جامعة الأزهر E-Mail: mnafea93@gmail.com

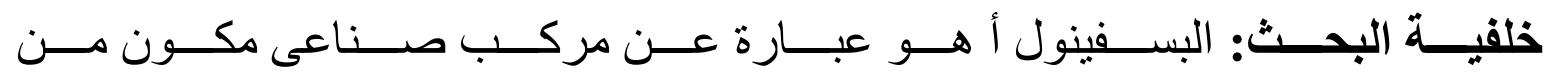
تكاتف مجمو عتين من الفينول وجزئ اسيتون واحد.

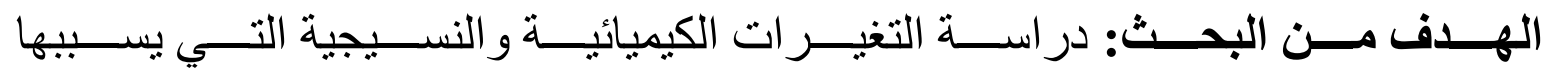

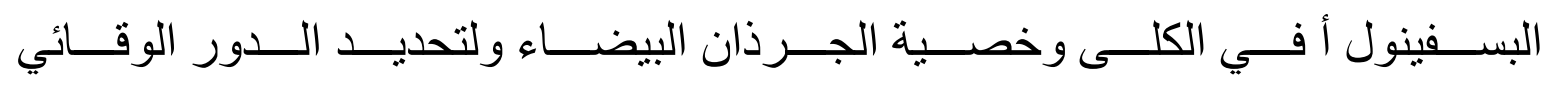
المحتمل لفيتامين سي على سمية البسفينول أ.

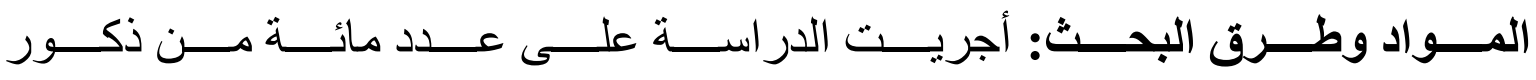

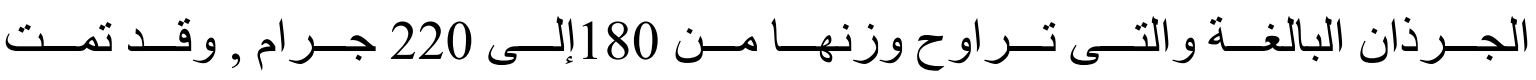

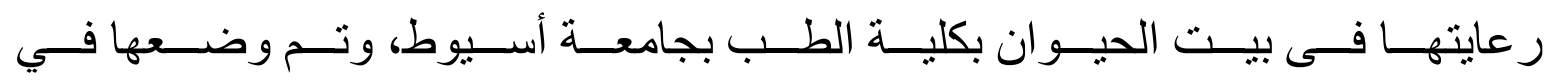

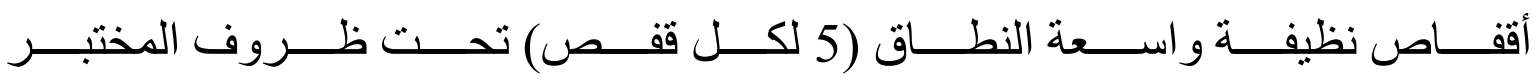

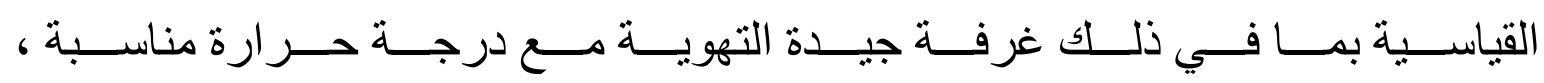

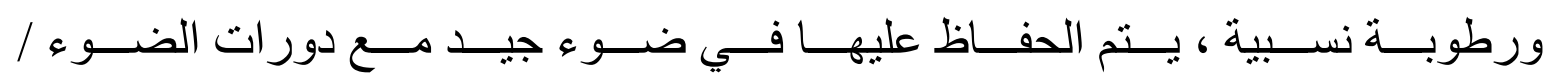

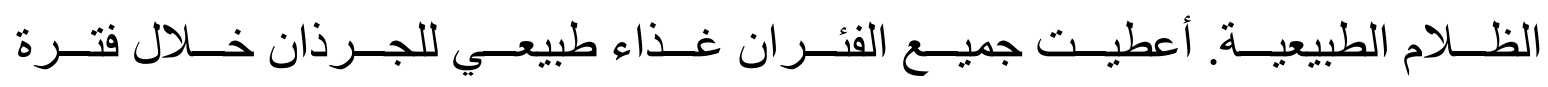
التجربة مع حرية الوصول إلى الماء.

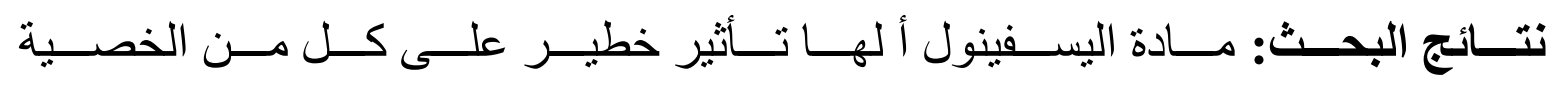

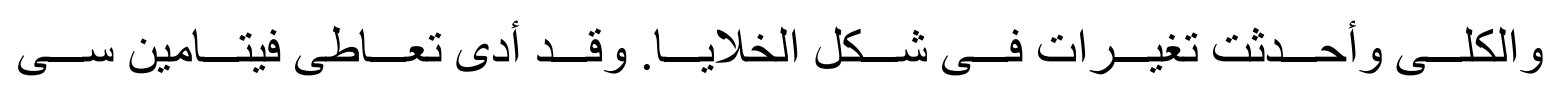

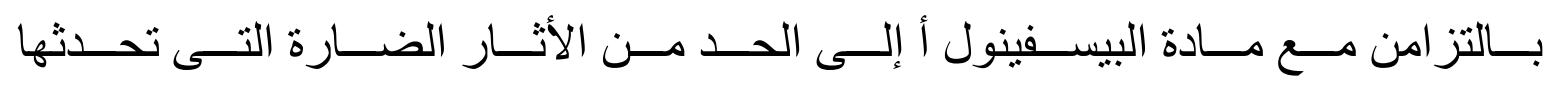

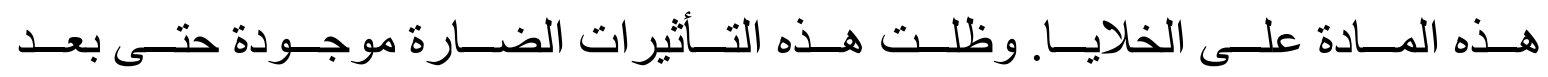




\section{MOHAMED NAFEA AL-SAYED et al.,}

التعــافى مــن مــادة البيسـفينول أ لمــدة أســـو عين بــل إن بعـض التــأثنير ات ازداد سو اء .

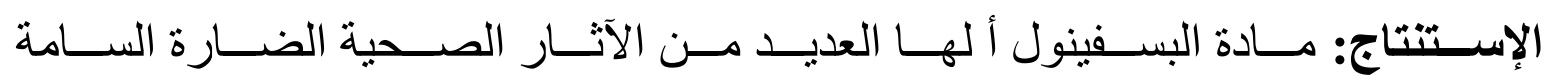
بما في ذلك السمية الإنجابية و الكلوية. الكلمات الدالة : البسفينول أ ، فيتامين سى، جرذان التجارب البيضاء. 